
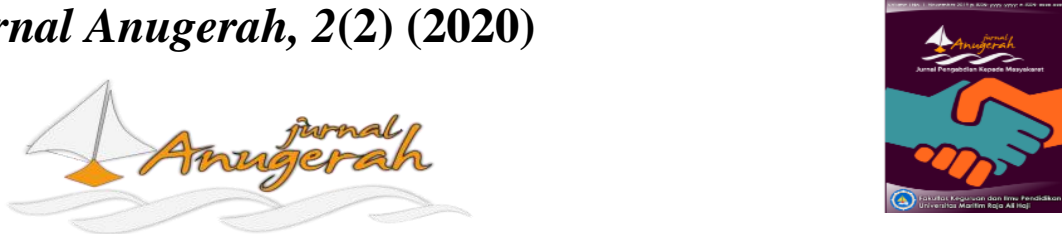

e-ISSN 2715-8179

https://ojs.umrah.ac.id/index.php/anugerah

\title{
Mengenal Nominal Sentences dengan Stepping the 5 Stairs “B” Teknik bagi Anak-anak Pesisir yang Belajar Grammar
}

\author{
Satria Agust", Gatot Subroto, Pradipta Agustina \\ Program Studi Pendidikan Bahasa Inggris, Universitas Maritim Raja Ali Haji \\ Tanjungpinang, Kepulauan Riau 29124, Indonesia \\ *e-mail korespondensi: satria.agust@umrah.ac.id
}

Pengiriman: 15 Oktober 2020; Diterima: 23 November 2020; Publikasi: 30 November 2020

DOI: https://doi.org/10.31629/anugerah.v2i2.2645

\begin{abstract}
Abstrak
Untuk mengonstruksi kalimat nominal bahasa Inggris perlu menggunakan teknik yang tepat. Teknik itu sendiri menawarkan iklim belajar yang menyenangkan dan mampu membuat penggunanya memahami konsep kontruksi kalimat tersebut dengan baik. Anak-anak pesisir perlu diperkenalkan dengan berbagai macam jenis teknik pembelajaran grammar, salah satunya Stepping the 5 Stairs "B". Grammar menjadi bagian penting dalam pembelajaran bahasa Inggris. Stepping the 5 Stairs " $B$ " merupakan teknik pembelajaran grammar yang ditawarkan oleh Tim PkM dan sudah didesain sesuai dengan karakteristik anak-anak pesisir tersebut. Tim PkM menggunakan pendekatan deskriptif sebagai metode pelaksanaan kegiatan PkM ini. Semua anggota Tim PkM turun ke lapangan untuk melakukan survei dan menginterview beberapa orang tua dan anak-anak pesisir. PkM ini telah dilaksanakan di Kelurahan Senggarang yang mana tempat ini terkenal dengan wisata religi bagi turis-turis asing. Kegiatan PkM ini menghasilkan: (1) Tingkat pemahaman anak-anak pesisir untuk mengonstruksi kalimar nominal bahasa Inggris meningkat dengan menerapkan teknik Stepping the 5 Stairs "B", (2) Motivasi belajar mereka sangat positif untuk belajar grammar dengan menggunakan Stepping the 5 Stairs " $B$ ", dan (3) Harapan perangkat desa, orang tua, dan juga anak-anak pesisir adalah bahwa kegiatan PkM ini tetap berlanjut karena Senggarang merupakan tempat tujuan wisatawan asing.
\end{abstract}

Kata kunci: anak-anak pesisir; grammar; Stepping the 5 Stairs "B"

\begin{abstract}
To construct nominal sentences in English, it is necessary to use the right technique. The technique itself offers a pleasant learning climate and is able to make users understand the concept of sentence construction well. Coastal children need to be introduced to various types of grammar learning techniques, one of which is the Stepping the 5 Stairs "B". Grammar is an important part of learning English. Stepping the 5 Stairs "B" is a grammar learning technique offered by the community service Team and has been designed according to the characteristics of these coastal children. The community service team used a descriptive approach as the method of implementing this community service activity. All members of the community service team went to the field to survey and interview some of the parents and coastal children. This community service was held in Senggarang Village, which is famous for religious tourism for foreign tourists. This community service activity resulted: (1) The level of understanding of coastal children in constructing nominal English sentences was increased by applying the Stepping the 5 Stairs "B" technique, (2) Their learning motivation was very positive for learning grammar using the Stepping the 5 Stairs "B", and (3) The expectations of village officials, parents, and coastal children are that this PkM activity will continue because Senggarang is a destination for foreign tourists.
\end{abstract}

Keywords: coastal students; grammar; Stepping the 5 Stairs "B" 


\section{Pendahuluan}

Stepping the 5 Stairs "B" merupakan teknik pembelajaran grammar yang ditemukan dan didesain oleh Agust dan Subroto pada tahun 2020. Teknik ini didesain untuk membantu mahasiswa dalam mengonstruksi kalimat-kalimat nominal bahasa Inggris. Ada sembilan langkah pembelajaran yang terdapat dalam teknik Stepping the 5 Stairs "B" tersebut. Sebenarnya, teknik ini berseri atau diberi seri dengan huruf mutu "B". Sebelum teknik seri "B" didesain, teknik seri "A" sudah didesain terlebih dahulu dan diberi nama Stepping the 5 stairs " $A$ ". Teknik seri " $\mathrm{A}$ " didesain untuk memudahkan mahasiswa dalam mengonstruksi kalimatkalimat bahasa Inggris yang menggunakan full-verb (Agust, 2017).

Grammar masih tetap dipelajari pada semua jenjang pendidikan. Banyak juga dari mereka yang mempelajari grammar beranggapan bahwa belajar grammar itu sangat sulit. Ditambah lagi dengan jumlah tenses yang beragam dan semakin membingungkan mereka kapan harus menggunakan tenses yang tepat dalam mengonstruksi kalimat bahasa Inggris. Pada jenjang pendidikan tinggi, grammar juga masih menduduki peringkat tertinggi untuk mata kuliah yang sulit dimengerti. Sebuah penelitian pada satu perguruan tinggi mengungkapkan bahwa secara umum terdapat 200 siswa yang tidak menyukai grammar dengan alasan tertentu. Delapan puluh siswa (40\%) tidak menyukai grammar karena materinya sulit dipahami dan 120 (60\%) tidak suka grammar karena guru mereka tidak mengajar dengan baik sehingga mereka mengalami kesulitan untuk mempelajarinya (Agust, 2019). Studi di Universitas Negeri Yogyakarta menekankan bahwa untuk menguasai grammar tidak mudah bagi mahasiswa semester akhir (Pratiwi, Triastuti, \& Nurhayati, 2020). Berdasarkan hasil survei yang pelaksana pengabdian lakukan, grammar merupakan pelajaran yang kurang mendapatkan perhatian dari kalangan mahasiswa. Ada dua faktor yang menyebabkan ketidaksukaan ini, yakni faktor internal dan eksternal. Faktor internal berasal dari pelajarpelajar grammar itu sendiri yang mana mereka tidak tertarik dan tidak suka belajar grammar, sedangkan dari faktor eksternal, mereka punya sejarah yang kurang baik dalam belajar grammar yang mana metode atau model yang guru-guru bahasa Inggris mereka gunakan kurang menarik (Agust, Subroto, \& Candra, 2019). Pada saat belajar grammar, mereka menyampaikan bahwa grammar membuat mereka gerah dan menyeramkan (Al-mekhlafi \& Nagaratnam, 2011).

Situasi dan kondisi seperti ini sepertinya juga dirasakan dan sudah terdesain dengan baik bagi anakanak pesisir. Pola pikir seperti ini selalu berada bersama mereka. Selama ini, para ekspertis tetap berupaya untuk menemukan model-model atau pendekatan-pendekatan baru untuk mengatasi masalah ini dalam konteks bahasa Inggris sebagai bahasa asing dan bahasa Inggris sebagai bahasa kedua. Sejauh ini, pengajaran grammar dalam konteks bahasa Inggris sebagai bahasa asing dan bahasa Inggris sebagai bahasa kedua hidup kembali dengan terbitnya sejumlah publikasi tentang pentingnya dan manfaat pengajaran grammar guna memperoleh bahasa (Ellis, 2005; Ellis, 2001, 2002; Philp, 2003; Yuan \& Ellis, 2003) serta diikuti dengan publikasi-publikasi tentang teori tekini dan model-model baru terkait pengajaran grammar (Conrad, 2000; Ellis, 1995; Hahn, 2000; Hinkel \& Fotos, 2002; Hughes \& McCarthy, 1998; Liu, 2003).

Faktanya adalah tawaran para ekspertis masih dianggap belum bisa menjawab masalah para pelajar grammar. Model pembelajaran grammar konvensional hingga berbasis komputer, seperti Computer-Assisted Language Learning (CALL) juga berkontribusi pada pelajaran grammar. CALL hanya bisa diimplementasikan pada lingkungan pelajar tertentu, khususnya bagi sekolah-sekolah yang telah memiliki sarana dan prasarana yang mendukung. Ragan, Boyce, Redwine, Savenye, \& C., (1993) mengklaim bahwa penggunaan multimedia menghemat waktu belajar sampai 30\% daripada penggunaan model konvensional. Ini kembali lagi pada konteks lingkungan belajarnya seperti apa. Model tradisional dirasa lebih efektif ketika multimedia tidak tersedia di lingkungan belajar.

Belajar bahasa biasanya berfokus pada komunikasi namun masih tetap terkendala pada masalah grammar. Meskipun pelajar bahasa cukup kompeten dalam berkomunikasi bahasa Inggris, masih tetap ditemui kesalahan grammar-nya (Harley \& Swain, 1984; Patsy M Lightbown \& Spada, 1990). Grammar 
menjadi sub tersendiri dalam belajar bahasa Inggris di perguruan tinggi. Kelas bahasa Inggris tradisional menganggap bahwa belajar bahasa berarti untuk mengenal bentuk kata serta tata bahasanya seperti kata kerja, kata benda, dan lain-lain. Pelajaran bahasa di sekolah jarang menyentuh pada kemampuan berbicara dan menulis dan lebih cenderung pada penguasaan aturan tata bahasa. Cara belajar seperti ini disesuaikan dengan pendekatan komunikatif dan tetap mengimbangi keterampilan-keterampilan bahasa yang lainnya seperti menulis, membaca, grammar, dan kosakata (Majeed \& Sama, 2018). Pandangan modern tentang pembelajaran bahasa Inggris adalah bahwa metode pengajaran bahasa telah berubah dengan adanya teknologi (Abbas, 2018). Para guru seharusnya mendorong peserta didik untuk mencari kegiatan-kegiatan yang sesuai dengan memanfaatkan teknologi komputer agar pembelajaran bahasanya berhasil (Genclter, 2015).

Pengajaran grammar walaupun bisa diajarkan terpisah secara tradisional juga bisa diterapkan dengan metode pembelajaran terintegrasi. Metode pembelajaran ini tidak menjadikan grammar sebagai fokus dalam belajar bahasa. Akan tetapi, para siswa bisa mengerti konteks bagaimana tenses tertentu berada pada suatu konteks yang tepat. Keunggulan pembelajaran terintegrasi bagi siswa akan mengasah kemampuan komunikasi. Akan tetapi, kemampuan berkomunikasi yang baik tersebut tidak selaras dengan kualitas ujaran yang dihasilkan. Aspek-aspek grammar bisa disajikan dan diuji dalam konteks yang sama tetapi tidak bisa diuji dalam konteks komunikatif (Lightbown, 2008).

Sebelum Kurikulum 2013 diterapkan, bahasa Inggris merupakan mata pelajaran wajib di sekolahsekolah. Di beberapa negara seperti Korea, Hongkong, China, Thailand, dan Indonesia, bahasa Ingris diperkenalkan pada anak-anak usia dini. Istilahnya adalah Teaching English to Young Learners. Di Indonesia, bahasa Inggris diajarkan kepada para siswa dari jenjang Sekolah Dasar sampai ke jenjang perguruan tinggi. Dengan waktu yang cukup lama untuk belajar bahasa Inggris, tetap saja para siswa tersebut sulit berkomunikasi menggunakan bahasa Inggris dengan baik. Muncul pertanyaan apa penyebabnya dan mengapa ini bisa terjadi?

Perlu langkah-langkah yang komprehensif untuk menjawab dua pertanyaan tersebut. Beberapa kemungkinannya bisa dideskripsikan sebagai berikut (1) kesalahan ada pada pengajarnya yang kurang memaksimalkan model pembelajaran yang dipilih. Strategi mengajar yang digunakan juga merupakan salah satu faktor kesulitan siswa dalam berbicara bahasa Inggris (Rabab'ah, 2005); (2) terlalu sibuk dengan pemenuhan kebutuhan administrasi daripada kompetensi. Kompetensi strategis dan kompetensi komunikasi kurang cakap (Rabab'ah, 2005); (3) terlalu mengandalkan teks daripada konteks bahasa Inggris; (4) masalah siswa, yakni bahasa Inggris kurang disenangi. Berbicara menggunakan bahasa Inggris bukan menjadi kebutuhan siswa (Hosni, 2014); (5) sarana dan prasarana pembelajaran bahasa Inggris belum memadai; dan (6) sejarah siswa belajar bahasa inggris kurang baik. Tidak memberikan kesempatan kepada pelajar untuk berpartisipasi dalam berbicara bahasa Inggris juga merupakan faktor lainnya (Hosni, 2014). Masih ada banyak lagi kemungkinan-kemungkinan yang bisa digali.

Konteks bahasa Inggris di Indonesia masih sebagai bahasa asing. Belajar bahasa Inggris pun hanya sebatas pemenuhan administrasi di sekolah. Di samping itu, mindset para siswa masih belum berubah yang menganggap bahasa Inggris merupakan pelajaran yang sulit, khususnya lagi pada grammar. Para pakar juga berpendapat bahwa grammar mempunyai tingkat kesukaran yang paling tinggi untuk dipelajari oleh para pelajar bahasa. Perlu terobosan baru untuk mengubah mindset negatif ini. Cara baru bisa dikenal dan diterapkan untuk membantu mereka mengubah mindset tersebut, yakni Stepping the 5 Strairs "B". Stepping the 5 Stairs " $B$ " adalah suatu teknik untuk belajar grammar yang telah dikembangkan dan akan terus dikembangkan oleh tim PkM.

Teknik ini sangat bisa untuk membantu para siswa memahami grammar dengan baik dan menawarkan suatu pembelajaran yang menyenangkan. Stepping the 5 Stairs "B" sangat praktis dan mampu meningkatkan nilai grammar mahasiswa. Setelah diujicoba pada level mahasiswa, teknik ini akan diuji pada 
JURNAL ANUGERAH, November 2020; Vol 2(2): 43 - 50

e-ISSN 2715-8179

level pendidikan di bawahnya guna mengembangkan teknik tersebut dan untuk mencari efektivitasnya pada anak-anak pesisir. Di samping itu, teknik ini menawarkan konsep pembelajaran tidak seperti sedang belajar namun sedang menggambar. Stepping the 5 Strairs " $B$ " menciptakan suasana belajar grammar lebih santai dan tetap menyenangkan serta menawarkan akurasi pada saat penggunanya mengonstruksi kalimat bahasa Inggris.

\section{Metode}

Tim pelaksana pengabdian menggunakan pendekatan deskriptif sebagai metode pelaksanaan PkM, yakni dengan melakukan advokasi atau pendampingan. Beberapa waktu sebelum melakukan kegiatan PkM, tim terjun ke lapangan tempat pengabdian di Kelurahan Senggarang dan menginterview beberapa perwakilan dari target atau subjek PkM terkait kesediaan mereka untuk mengenal nominal sentences dalam bahasa Inggris dengan menggunakan teknik Stepping the 5 Stairs "B". Teknik ini seperti yang sudah dijelaskan sebelumnya digunakan untuk membantu siswa dan siswi mengonstruksi kalimat-kalimat nominal bahasa Inggris dengan akurat dan benar. Desain teknik ini sama seperti tangga yang terdiri dari lima anak tangga. Kelima anak tangga tersebut mempunyai fungsinya masing-masing (Agust, 2017, 2019). Subjek PkM ini adalah anak-anak usia sekolah yang berumur 10-12 tahun. Mereka terdiri dari 8 laki-laki dan 7 perempuan. Lokasi PkM yakni Senggarang yang terkenal dengan vihara dan menjadi wisata religi bagi turis, khususnya turis yang berasal dari Cina. PkM telah dilaksanakan selama 2 pertemuan dari 4 pertemuan yang direncanakan, yakni pada tanggal 18 dan 25 Juli 2020. Hasil PkM ini telah dianalisa sedemikian rupa melalui metode deskriptif. Tim PkM menggunakan angket yang terdiri dari 10 (sepuluh) item. Tim PkM menggunakan Rasch Model untuk memvalidasi dan menguji realibilitas angket yang telah disebarkan kepada peserta PkM.

Tim PkM memperkenalkan diri terlebih dahulu yang terdiri dari 3 (tiga) dosen dan 4 (empat) mahasiswa semester 5 kepada perangkat desa seperti Pak RW, Pak RT, orang tua peseta PkM, dan anak-anak pesisir yang menjadi target dalam kegiatan PkM. Tim PkM kemudian membentuk 4 (empat) kelompok belajar kecil untuk mengonstruksi kalimat-kalimat nominal bahasa Inggris dengan teknik Stepping the 5 Stairs " $B$ " di taman Vihara Senggarang. Tingkat keberhasilan PkM dilihat melalui 4 (empat) indikator, yakni: (1) 98\% peseta PkM menunjukkan keaktifannya pada saat PkM dilaksanakan; (2) Jumlah pertemuan PkM mencapai 50\% pada saat pandemi Covid-19 sempat hilang di Tanjungpinang; (3) Peserta PkM berharap agar kegiatan ini berkelanjutan; dan (4) Sebanyak 14/15 atau setara dengan 93.33\% peserta PkM telah memahami dan mampu menggunakan teknik Stepping the 5 Stairs "B" untuk mengonstruksi kalimat nominal bahasa Inggris.

\section{Hasil dan Pembahasan}

Selama kegiatan PkM berlangsung, Tim PkM mengamati peserta PkM, yang mana mereka merasa tegang ketika belajar grammar bersama Tim PkM. Di sela-sela proses pembelajaran, Tim PkM mewawancarai mereka tentang pengalaman mereka belajar grammar. Mereka menyatakan bahwa mereka masih sangat kurang memahaminya. Hasil PkM ini mengkonfirmasi hasil kegiatan PkM yang dilakukan oleh Risnawaty (2018) bahwa peserta PkM mempunyai kendala dalam praktik bahasa Inggris dan perlunya kegiatan yang berkesinambungan. Beberapa peserta PkM masih belum bisa berkomunikasi dalam bahasa Inggris dengan benar. Tim PkM hadir selama 2 (dua) pertemuan untuk mengenalkan cara baru untuk mengonstruksi kalimat nominal bahasa Inggris dengan Stepping the 5 Stairs "B". Teknik ini didesain untuk menciptakan iklim belajar yang santai dan menyenangkan. Teknik ini didesain untuk mengonstruksi kalimatkalimat nominal dalam bahasa Inggris dari beberapa tenses. Gambar 1 menggambarkan suasana pembelajaran peserta $\mathrm{PkM}$. 


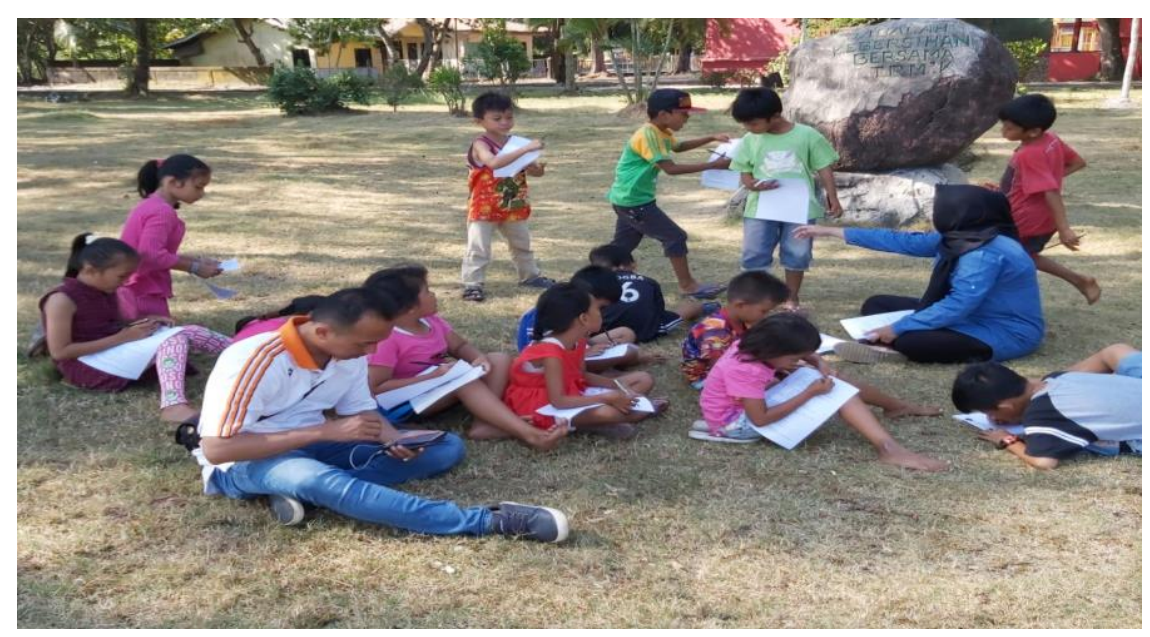

Gambar 1. Suasana pembelajaran anak-anak pesisir pada pertemuan pertama

Tim PkM mewawancarai para peserta PkM "Bagaimana rasanya belajar Grammar? Respons mereka adalah grammar itu terlalu banyak tenses dan bingung mau gunakan yang mana satu dalam percakapan serta sulit dipahami. Hasil wawancara ini juga mengkonfirmasi hasil wawancara PkM yang dilakukan oleh Romadhon \& Sungkar (2020) yang mengungkapkan bahwa para siswa mengalami kesulitan dalam menguasai grammar dan kosakata bahasa Inggris. Pernyataan ini sejalan dengan hasil PkM Hasanah (2016). Menurut peserta PkM, internet pun bukan juga sarana yang efektif dan maksimal untuk belajar grammar karena belajar grammar di kelas dirasa lebih efektif dan menambah pemahaman mereka. Konfirmasi oleh Agust (2017) adalah bahwa dari 80/200 mahasiswa (40\%) mengakui bahwa mereka tidak suka dengan materi grammar dan 120/200 diantaranya (60\%) mengakui bahwa guru bahasa Inggris mereka merupakan penyebab ketidaksukaan mereka terhadap grammar. Masalah sebenarnya bukan ada pada guru tetapi pikiran negatif pelajar bahasa tentang grammar. Penelitian yang melibatkan 82 mahasiswa Pendidikan Bahasa Inggris menemukan passion yang berbeda pada aspek-aspek bahasa Inggris. Yang suka pronunciation sebesar 64\%, vocabulary sebesar $25 \%$, dan grammar sebesar $11 \%$. Persentase tertinggi jatuh pada pronunciation menjadi persentase tertinggi, yang diikuti oleh vocabulary dan grammar. Grammar sangat tidak disukai (Agust, 2019).

Pertemuan kedua PkM menunjukkan hasil yang positif di mana peserta PkM sudah tidak tegang dalam mengonstruksi kalimat nominal. Pada pertemuan pertama, mereka masih melakukan kesalahankesalahan minor seperti noun phrase 1, copula, complement, dan adverbs of manner, place, time dalam mengonstruksi kalimat-kalimat nominal bahasa Inggris. Kekeliruan yang mereka lakukan terjadi karena mereka belum menerapkan teknik Stepping the 5 Stairs "B" dengan konsisten dan benar. Pada pertemuan kedua, Tim PkM kembali mengingatkan mereka untuk lebih konsisten dan mengonstruksi kalimat-kalimat nominal itu dengan teliti. Setelah diamati, hasil kalimat-kalimat nominal yang dikonstruksi sudah benar. Dengan mengikuti langkah-langkah Stepping the 5 Stairs " $B$ ", mereka berhasil membuat kalimat nominal bahasa Inggris dengan benar. Hasil PkM ini mengkonfirmasi hasil PkM yang dilakukan oleh Romadhon \& Sungkar (2020) yang menyatakan bahwa metode Make a Match mampu membuat peserta PkM paham tentang grammar dan vocabulaty dan mereka mengatakan bahwa Make a Match merupakan metode yang menyenangkan. Dengan demikian, kepiawaian guru dalam memilih dan menerapkan suatu teknik atau media pembelajaran bahasa Inggris bisa memberi solusi terhadap anak-anak pesisir dalam mengonstruksi kalimat nominal bahasa Inggris. 


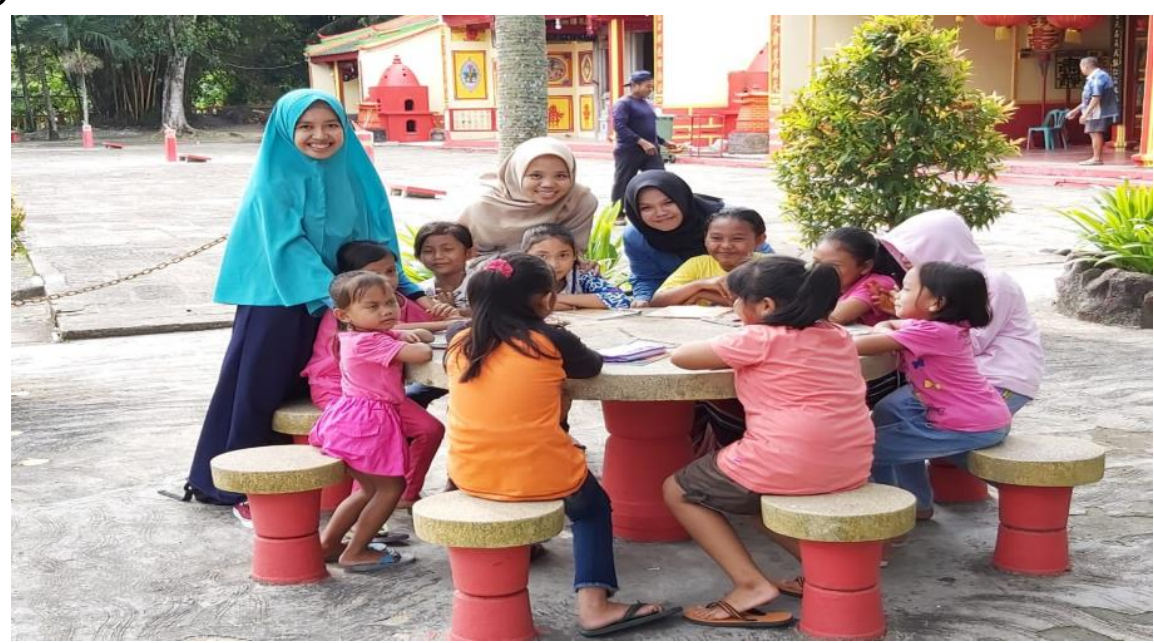

Gambar 2. Pelaksanaan PkM pada pertemuan kedua di Taman Vihara Senggarang

Tim PkM juga mengamati bahwa anak-anak pesisir sudah mampu secara individu untuk membuat kalimat nominal bahasa Inggris dengan benar dan akurat. Soft skill seperti kerja sama dan motivasi peserta PkM mulai tumbuh dengan menerapkan teknik Stepping the 5 Stairs " $B$ ". Tim PkM sudah tidak memainkan peran $100 \%$ karena mereka merupakan fasilitator dan tetap memonitor proses pembelajaran. Kemudian, Tim PkM melihat bahwa adanya keseriusan dari peserta PkM yang ingin kegiatan PkM ini tetap lanjut. Peserta PkM mempunyai pandangan yang sangat positif terkait pelaksanaan PkM ini dan semua atau 100\% peserta PkM yang merupakan anak-anak pesisir merasa sangat setuju seandainya kegiatan PkM ini dilanjutkan.

\section{Kesimpulan}

Penggunaan Stepping the 5 Stairs " $B$ " dalam mengonstruksi kalimat nominal bahasa Inggris sangat memungkinkan untuk diaplikasikan di lokasi-lokasi PkM yang lainnya untuk jangka panjang. Keberhasilan kegiatan PkM ini bisa dilihat dari:

1. Tingkat pemahaman anak-anak pesisir untuk mengonstruksi kalimar nominal bahasa Inggris meningkat dengan menerapkan teknik Stepping the 5 Stairs "B".

2. Motivasi belajar mereka sangat positif untuk belajar grammar dengan menggunakan Stepping the 5 Stairs "B".

3. Harapan perangkat desa, orang tua, dan juga anak-anak pesisir adalah bahwa kegiatan PkM ini tetap berlanjut karena Senggarang merupakan tempat tujuan wisatawan asing.

Selama pelaksanaan PkM, ada beberapa kekurangan yang dihadapi antara lain:

1. PkM ini dilaksanakan pada masa Pandemi Covid-19 sehingga target 4 kali pertemuan yang diinginkan tim PkM ini tidak dapat terpenuhi.

2. Ketidakhadiran salah satu anggota tim PkM dirasa sedikit menghambat pelaksanaan kegiatan.

3. Ketidaktercapaian target jumlah pertemuan kegiatan PkM ini, 4 pertemuan, sangat menghambat untuk memaksimalkan pemahaman peserta $\mathrm{PkM}$ tentang mengonstruksi kalimat nominal bahasa Inggris dengan Stepping the 5 Stairs " B".

\section{Saran}

Beberapa saran terkait pelaksanaan kegiatan PkM ini dapat dideskripsikan sebagai berikut dengan mempertimbangkan beberapa aspek lain:

1. Kegiatan PkM ini bisa melibatkan peserta yang lebih banyak jika pandemi Covid-19 sudah berakhir.

2. Mengenal dan mengimplementasikan teknik Stepping the 5 Stairs "B" dengan lebih intens guna memaksimalkan pemahaman peserta PkM dalam mengonstruksi kalimat nominal bahasa Inggris. 
3. Penggunaan teknik Stepping the 5 Stairs "B" bisa diterapkan di sekolah-sekolah tempat peserta PkM menuntut ilmu untuk membantu para siswa mengonstruksi kalimat nominal bahasa Inggris dengan baik.

4. Kegiatan PkM yang dilakukan secara reguler dan berkelanjutan sesuai harapan perangkat desa, orang tua, dan juga peserta PkM perlu didukung dengan anggaran yang memadai.

\section{Ucapan Terima Kasih}

Seluruh anggota Tim PkM mengapresiasi dan mengucapkan terima kasih kepada LP3M UMRAH atas fasilitas dan dukungan sehingga kegiatan PkM ini dapat dilaksanakan. Apresiasi berikutnya ditujukan kepada mahasiswa/i Pendidikan Bahasa Inggris, Fakultas Keguruan dan Ilmu Pendidikan, Universitas Maritim Raja Ali Haji yang turut berperan aktif dalam pelaksanaan PkM ini, yakni Zethro Genik Dewangga, Diah Novrianty Utami, Sri Dwi Nurbayti, dan Elvinasafira.

\section{Referensi}

Abbas, P. G. (2018). The use of technology in English language learning: A literature review. International Journal of Research in English Education, 115-125.

Agust, S. (2017). Mastering the advanced grammar by stepping the 5 stairs up. Tanjungpinang: UMRAH Press.

Agust, S. (2019). Let's step the stairs to learn grammar. Tanjungpinang: UMRAH Press.

Agust, S., Subroto, G., \& Candra, M. (2019). Pentingnya stepping the 5 stairs "A" teknik untuk anak-anak pesisir yang belajar grammar. Jurnal Anugerah, 1(1), 41-49. https://doi.org/10.31629/anugerah.v1i1.1610

Al-mekhlafi, A. M., \& Nagaratnam, R. P. (2011). Difficulties in teaching and learning grammar in an EFL context. International Journal of Instruction, 4(2), 69-92.

Conrad, S. (2000). Grammar Teaching in the 21st Century ? *. Tesol Quarterly, 1999(April), 548-560.

Ellis, N. C. (2005). At the interface: Dynamic interactions of explicit and implicit language knowledge. Studies in Second Language Acquisition, 27(2), 305-352. Retrieved from http://www.jstor.org/stable/44486825

Ellis, R. (1995). Interpretation tasks for grammar teaching. TESOL Quarterly, 29(1), 87. https://doi.org/10.2307/3587806

Ellis, R. (2001). Investigating form-focused instruction. In R. Ellis (Ed.), Form-focused instruction and second language learning. Malden: Blackwell Publishing.

Ellis, R. (2002). Does form-focused instruction affect the acquisition of implicit knowledge? A Review of the Research. Studies in Second Language Acquisition, 24(2), 223-236. Retrieved from http://www.jstor.org/stable/44486614

Genclter, B. (2015). How does technology affect language learning process at an early age? Procedia Social and Behavioral Sciences, 311-316.

Hahn, A. (2000). Grammar at its best: The development of a rule- and corpus-based grammar of English tenses. In L. Bernard \& T. McEnery (Eds.), Rethinking language pedagogy from a corpusbased perspective. Bern: Peter Lang.

Harley, B., \& Swain, M. (1984). The interlanguage of immersion and its implications for second language teaching. In A. Davies, C. Criper, \& A. P. R. Howatt (Eds.), Interlanguage (pp. 291-311). Edinburgh: Edinburgh University Press.

Hasanah, H. U. (2016). Respon mahasiswa terhadap pembelajaran grammar berbasis website. NUANSA: Jurnal Penelitian Ilmu Sosial Dan Keagamaan Islam, 13(1).

Hinkel, E., \& Fotos, S. (2002). New perspectives on grammar teaching in second language classrooms. Mahwah, NJ: Erlbaum. 
JURNAL ANUGERAH, November 2020; Vol 2(2): 43 - 50

e-ISSN 2715-8179

Hosni, S. A. (2014). Speaking difficulties encountered by young EFL learners. International Journal on Studies in English Language and Literature, 22-30.

Hughes, R., \& McCarthy, M. (1998). From sentence to discourse: Discourse grammar and English language teaching. TESOL Quarterly, 32(2), 263. https://doi.org/10.2307/3587584

Lightbown, P. M. (2008). Transfer appropriate processing as a model for classroom second language acquisition. In Z. Han (Ed.), Understanding second language process (pp. 27-44). Clevedon, UK: Multilingual Matters. Retrieved from https://www.researchgate.net/profile/Patsy_Lightbown/publication/292461381_Transfer_appropriate_ processing_as_a_model_for_classroom_second_language_acquisition/links/5785032008aec5c2e4e10f 04/Transfer-appropriate-processing-as-a-model-for-classroom-second-

Lightbown, P. M., \& Spada, N. (1990). Focus-on-form and corrective feedback in communicative language teaching: Effects on second language learning. Studies in Second Language Acquisition, 12(4), 429448.

Liu, D. (2003). Grammar teaching in teacher education. (D. Liu \& P. Master, Eds.). International TESOL Association.

Majeed, M. N. A., \& Sama, F. R. F. (2018). Teaching grammar in the English language classroom: Perceptions and practices of students and teachers in the Ampara district. In Proceedings of 7 th International Symposium (pp. 653-667).

Philp, J. (2003). Constraints on "NOTICING THE GAP": Nonnative speakers' noticing of recasts in NSNNS interaction. Studies in Second Language Acquisition, 25(1), 99-126. Retrieved from http://www.journals.cambridge.org/abstract_S0272263103000044

Rabab'ah, G. (2005). Communication problems facing Arab learners of English. Journal of Language and Learning, 180-197.

Ragan, T., Boyce, M., Redwine, D., Savenye, W., \& C., M. J. (1993). Is multimedia worth it? Association for Educational Communications and Technology Convention.

Risnawaty. (2018). Pelatihan bahasa Inggris melalui media gambar dengan direct method (metode langsung). In Prosiding Seminar Nasional Hasil Pengabdian 2018 (pp. 323-327).

Romadhon, S. A., \& Sungkar, M. S. (2020). Peningkatan vocabulary dan grammar dengan menggunakan metode Make a Match bagi siswa panti asuhan Putera Muslimat Brebes. Jurnal Pendidikan Pembelajaran Pemberdayaan Masyarakat, 175-180.

Yuan, F., \& Ellis, R. (2003). The effects of pre-task planning and on-line planning on fluency, complexity and accuracy in L2 monologic oral production. Applied Linguistics, 24(1), 1-27. https://doi.org/10.1093/applin/24.1.1 